\title{
Transactivation Function-1-Mediated Partial Agonist Activity of Selective Estrogen Receptor Modulator Requires Homo-Dimerization of the Estrogen Receptor $\alpha$ Ligand Binding Domain
}

\author{
Yukitomo Arao * (10) and Kenneth S. Korach * \\ Receptor Biology Section, Reproductive and Developmental Biology Laboratory, National Institute of \\ Environmental Health Sciences/NIH, Durham, NC 27709, USA \\ * Correspondence: araoy@niehs.nih.gov (Y.A.); korach@niehs.nih.gov (K.S.K.)
}

Received: 24 June 2019; Accepted: 26 July 2019; Published: 30 July 2019

\begin{abstract}
The isolation of estrogen receptor alpha (ER $\alpha)$ cDNA was successful around 30 years ago. The characteristics of ER $\alpha$ protein have been examined from various aspects, primarily through in vitro cell culture studies, but more recently using in vivo experimental models. There remains, however, some uncharacterized $\mathrm{ER} \alpha$ functionalities. In particular, the mechanism of partial agonist activity of selective estrogen receptor modulators (SERMs) that involves control of the N-terminal transcription function of ER $\alpha$, termed AF-1, is still an unsolved ER $\alpha$ functionality. We review the possible mechanism of SERM-dependent regulation of ER $\alpha$ AF-1-mediated transcriptional activity, which includes the role of helix 12 of ER $\alpha$ ligand binding domain (LBD) for SERM-dependent AF-1 regulation. In addition, we describe a specific portion of the LBD that associates with blocking AF-1 activity with an additional role of the F-domain in mediating SERM activity.
\end{abstract}

Keywords: estrogen receptor alpha; selective estrogen receptor modulator; homo-dimerization; ligand binding domain; F-domain; AF-1

\section{Introduction}

Estrogen receptor alpha $(\mathrm{ER} \alpha)$ is the first estrogen receptor protein that the cDNA was isolated from various species, including human, mouse, rat and chicken [1-4]. Since then, ER $\alpha$ protein has been examined extensively. However, there are some ER $\alpha$ protein functionalities that remain uncharacterized. The molecular mechanism of partial agonist activity of selective estrogen receptor modulators (SERMs), controlling the N-terminal transcriptional activity of ER $\alpha$ is still unsolved. In this review, we describe a cooperative functionality of the ER $\alpha$ protein domains for eliciting a tissue selective gene response by controlling the $\mathrm{N}$-terminal transcriptional activity.

$\mathrm{ER} \alpha$ is a member of the nuclear receptor superfamily that includes the receptors for various lipid-soluble bioactive compounds, such as steroid hormones, vitamin A, vitamin $\mathrm{D}$ and bioactive-lipids [5-7]. Members of the nuclear receptor superfamily work as ligand-dependent transcription regulators, which possess six highly conserved structural and functional domains termed A through F. As the ligand-dependent transcription regulators, the family members contain a highly conserved DNA binding domain (DBD) also known as the C-domain, and a ligand-binding domain (LBD) referred to as the E-domain. Additionally, each receptor contains more variable domains, termed AB-domains/N-terminal structure, D-domain/hinge region or connective region between $\mathrm{DBD}$ and LBD, and F-domain/C-terminal structure [7]. ER $\alpha$ possesses $\mathrm{A}$ through $\mathrm{F}$ domains and two transactivation functional regions, termed AF-1 and AF-2, which are localized in AB-domains and E-domain, respectively (Figure 1). 


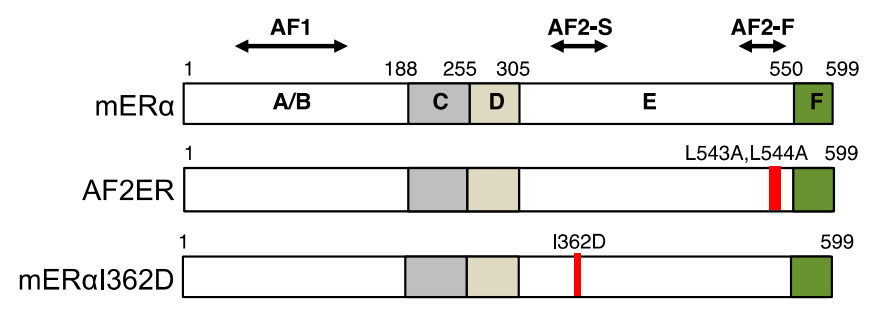

Figure 1. Schematic structure of mouse estrogen receptor $\alpha(\mathrm{mER} \alpha)$. ER $\alpha$ consists of six domains named A to F. C-domain binds to an estrogen responsive DNA element. The ligands bind to E-domain (ligand binding domain; LBD). A/B-domain possesses the transactivation function 1 (AF1). E-domain possesses ligand-dependent transcription activation domain (i.e., AF-2). AF-2 is composed of static region (AF2-S) and flexible region (AF2-F). AF2-F corresponds to the helix 12 of LBD. The schematic structures of AF2-F mutant (AF2ER) and AF2-S mutant (mER $\alpha$-I362D) are shown. Red bars indicate the position of mutated amino acids in the AF-2 mutants.

The transcriptional activity of AF-2 corresponds to the ligand-dependent transformation of LBD. Especially, the ligand-dependent relocation of the helix 12 of LBD defines the activity of estrogenic chemicals as agonists/ligands that activate transcription or antagonists/ligands that inactivate transcription. We have characterized the specific mutations in helix 12, named AF2ER (i.e., leucines 543 and 544 of mouse ER $\alpha$ were mutated to alanines; L543A, L544A) and found that the antagonists function as agonists through AF2ER mutant $\mathrm{ER} \alpha$ in vitro and in vivo [8,9]. A human ER $\alpha$ L540Q mutant, which mutated residue corresponds to the mouse ER $\alpha$ L544, possesses similar characteristics to AF2ER [10]. The first subsection of this review focuses on the functionality of ER $\alpha$ helix 12 for defining the agonistic or antagonistic activities of estrogenic chemicals based on our study using the AF2ER mutant.

The AF-1 is localized to the N-terminus of $E R \alpha$, which is not involved in the ligand binding. Thus, it has been reported that growth factors may modulate the activity of ER $\alpha$ AF-1-mediated transcription through phosphorylation of specific serine residues in the N-terminus, especially serines 104, 106 and 118 of human ER $\alpha$. Several in vitro studies have revealed specific protein kinases, such as mitogen-activated protein kinase and cyclin-dependent kinases which are potentially activated by growth factor signaling and induce phosphorylation of these serine residues [11-14]. In addition, a study using the global ER $\alpha$ knockout $(\mathrm{KO})$ mouse revealed that the growth factors (e.g., Igf1 and Egf)-dependent uterine epithelial cell proliferation was attenuated in the ER $\alpha$ KO mouse [15]; the observation has supported the in vivo biological functionality of ER $\alpha$ AF-1 phosphorylation. Recently, we found that the growth factors failed to induce uterine cell proliferation in the AF2ER mutant mouse, which expresses the ER $\alpha$ protein containing the intact AF-1 and the mutated AF-2 [8]. This result suggested that the proper AF-2 function is necessary for AF-1 activation. Additionally, we identified and reported that a specific region within AF-2 impacts the AF-1 activity [16]. The second subsection of this review describes the possible mechanism of AF-2/LBD-mediated regulation of AF-1 activity.

The length of the F-domain composing the very end of C-terminus is highly variable among the nuclear receptors. For instance, the ER $\alpha$ F-domain contains 50 amino acids that connect directly with helix 12 of the LBD. Because of the high variability in this region among the nuclear receptors, the functionality of F-domain of nuclear receptors is not well understood [17]. We found that the ER $\alpha$ F-domain is involved in the partial agonist activity of SERMs. The third subsection of this review describes the functionality of ER $\alpha$ F-domain for the regulation of SERM-dependent ER $\alpha$ AF-1-mediated transcriptional activity.

SERMs are non-steroidal ER ligands. These chemicals have been generated to treat postmenopausal women for reducing the symptoms of menopause, such as osteoporosis and hot flushes, or for treating breast cancer patients [18-25]. The symptoms of menopause could be normalized by the adjustment of female sex steroid hormone (e.g., 17ß-estradiol; E2) level. However, the treatment of E2 to patients affects broader ER $\alpha$-mediated physiological responses, causing various adverse side effects. The SERMs 
regulate the activities of ER $\alpha$ AF-1 and AF-2 different from E2. Thus, the treatment with SERMs potentially controls ER $\alpha$ AF-1 or AF-2-mediated physiological responses selectively for reducing side effects. A better understanding of the molecular mechanism of ligand-dependent regulation of ER $\alpha$ AF-1- and AF-2-mediated transcriptional activity related to physiological responses is beneficial for development of more appropriate therapies.

\section{The Mutation of Helix 12 Reverses Antagonistic Chemicals to Agonists}

X-ray crystallography of various nuclear receptors has verified that the overall structure of the LBD is highly conserved among the nuclear receptors. The studies showed that helix 12 , the last helix structure of the LBD, is repositioned in a ligand-dependent manner [26]. Specifically, when agonists bind to the ER $\alpha$ LBD, helix 12 cooperates with helices 3 and 4 to create a coactivator interacting surface for transactivation, i.e., AF-2 [27,28]. The receptor interacting motif of coactivators (leucine-x-x-leucine-leucine; LxxLL motif) fits to the cleft of the coactivator interacting surface of the LBD [28]. In contrast, when antagonists/SERMs, such as 4-hydroxytamoxifen (4OHT) bind to the ER $\alpha$ LBD, helix 12 is shifted to the position occupied by the LxxLL motif when agonists bind [29]. It is highly likely that the altered position of helix 12 with antagonists/SERMs prevents coactivator interaction, resulting in attenuation of ER $\alpha$ AF-2-mediated transcriptional activity. When the antagonists/selective estrogen receptor degraders (SERDs), such as fulvestrant/ICI182780 bind to the ER $\alpha$ LBD, helix 12 becomes free from the coactivator interacting surface [30]. This disturbed positioning of helix 12 which is different from that with SERMs is likely to provoke destabilization and proteolysis of the ER $\alpha$ protein [31,32]. Thus, helix 12 would appear to be an important domain for defining the characteristics of different $\mathrm{ER} \alpha$ ligands for the $\mathrm{ER} \alpha$ transactivation.

We have analyzed the functionality of a specific helix 12 mutated ER $\alpha$ (i.e., mouse ER $\alpha$ L543A-L544A or AF2ER) in vivo and in vitro [8,16,33-35]. Originally, Malcolm Parker's group reported the characteristics of a series of helix 12 mutants, including L543A-L544A and M547A-L548A mouse ER $\alpha$ mutants [36]. The residues of L543, L544, M547 and L548 are located on the same surface of helix 12. Compared to the wild-type ER $\alpha$, these ER $\alpha$ mutants were reported to exhibit reduced E2-mediated transcriptional activity measured with an estrogen-responsive reporter composed of the consensus estrogen responsive element (ERE) of the vitellogenin (Vit) gene in HeLa cells. In addition, the E2-mediated transcriptional activity was enhanced, rather than inhibited, by antagonists, such as 4OHT or ICI164384 (ICI; the first generation of fulvestrant analogue) [36]. Importantly, the report showed that the effect of antagonist-dependent enhancement was attenuated by truncation of the N-terminal/AB-domains of ER $\alpha$ [36]. They concluded that an intact AF- 1 domain is a prerequisite for antagonists-mediated transcriptional stimulation through L543A-L544A and M547A-L548A mutants [36]. The group proposed a possible mechanism for this action. Namely, the SERD (e.g., ICI)-mediated ER $\alpha$ proteolysis was attenuated by these mutations that may reflect the antagonist-dependent transactivation [32,36]. It was insufficient to explain how the AF-1 of mER $\alpha$ L543A-L544A (i.e., AF2ER) is activated by the antagonists.

We observed that the 3x VitERE-mediated transcriptional activity of the AF2ER mutant was intensified in HepG2 cells by various SERMs as well as 4OHT or fulvestrant/ICI182780 [35]. Additionally, we found that E2 was not necessary for antagonist-mediated activation of the AF2ER mutant, which was not addressed in the previous report of Mahfoudi et al [36]. Consistent with the previous study, we found that the AF2ER mutant was not activated by E2, and the antagonist-dependent activation was lost by truncation of the AB-domains of the AF2ER mutant [35]. These results clearly suggested that the AF-1 activity of the AF2ER mutant is dominant for antagonists-mediated transactivation. Further analyses using a mammalian two-hybrid assay $(\mathrm{M} 2 \mathrm{H})$ revealed that the antagonists induced homo-dimerization of AF2ER mutant, which was essential for enhancing transactivation function.

The lack of any ligand-dependent transcription activity of the AF2ER-LBD/EF-domains was an important finding [35]. This allowed us to use the mutant for a $\mathrm{M} 2 \mathrm{H}$ assay to examine the homo-dimerization activity of AF2ER-LBD. We found that the antagonist-dependent dimerization 
activity of AF2ER-LBD was obstructed by a dimerization disruption mutation (leucine 511 of mER $\alpha$ was substituted to arginine, L511R) [37] or by F-domain truncation. Interestingly, the homo-dimerization activity of helix 12 deleted mutant LBD ( $\mathrm{mER} \alpha$ LBD lacking 542-548 amino acids) was weak but similar to AF2ER-LBD [35]. Importantly, E2 and other agonists did not induce the homo-dimerization activity of AF2ER-LBD. The transcriptional activity of AF2ER mutant through 3x VitERE coincided with the LBD homo-dimerization activity [35]. Furthermore, we revealed that the dimerization disrupted AF2ER mutant (AF2ER-L511R) showed reduced ligand-dependent binding activity to the ERE DNA fragment [35]. These results suggested that the structure of helix 12 is disrupted by the AF2ER mutation and the flanking F-domain influences the antagonist-dependent dimerization of AF2ER-LBD; the dimerized AF2ER mutant can bind an ERE DNA sequence for transcriptional activation. The phenotypes of helix 12 deleted mutant mouse (i.e., mouse ER $\alpha$ lacking 539-554 amino acids or $\mathrm{ER} \alpha \mathrm{AF}^{0}$ ) have been reported as similar to the phenotypes of $\mathrm{ER} \alpha \mathrm{KO}$ or AF2ER mice [38,39]. Moreover, Movérare-Skrtic et al. reported that fulvestrant works as an agonist in uterus and trabecular bone in $\mathrm{ER} \alpha \mathrm{AF} 2^{0}$ mice [40]. This observation supported our speculation; the destruction of helix 12 structure reverses the function of $\mathrm{ER} \alpha$ antagonists. It is likely that the reversed antagonist activity occurs through the antagonist induced homo-dimerization of AF2ER mutant (i.e., helix 12 structure eliminated mutant) on the ERE which then allows exposure of the AF-1 domain for transcriptional activation.

\section{The Ligand-Dependent Regulation of ER $\alpha$ AF-1 Activity}

When the agonists bind to the ER $\alpha$ LBD, the flexible helix 12 (AF2-F) and the rigid helices 3 and 4 (AF2-S) form the transcription coactivator binding surface (Figure 1). In the structure of the agonist-bound hER $\alpha$ LBD complexed with the peptide of GRIP1 NR box II (i.e., LxxLL motif containing domain of SRC2), the corresponding residues of $\mathrm{mER} \alpha$ lysine 366 (K366) and glutamic acid 546 (E546) were shown to form hydrogen bonds with the LxxLL peptide [29]. It has previously been shown that the position of isoleucine 362 (I362) of $\mathrm{mER} \alpha$, which is localized on the helix 3, is adjacent to the L543 when E2 bound to the LBD (Figure 2). Mak et al. reported that the E2-dependent SRC1e-mediated coactivation function was strongly attenuated by the aspartic acid substitute at I362 (I362D). In contrast, the activity of alanine substituted mutant (I362A) was comparable to the wild-type $\mathrm{ER} \alpha$ [27]. The hydrophobic amino acids of AF-2 surface are important for stabilizing the hydrogen bonds between LxxLL motif and the residues of K366 and E546 [27]. The result from the I362D mutant suggested that the irregular surface charge of this area disrupts the agonist-dependent coactivator recruitment to the AF-2. We have characterized the activity of the $m E R \alpha$ I362D mutant, which is another E2-insensitive AF-2 mutant ER $\alpha$ having a mutation on the rigid region of AF-2 in contrast to the mutation of the flexible region of AF-2 (i.e., AF2ER) (Figure 1).

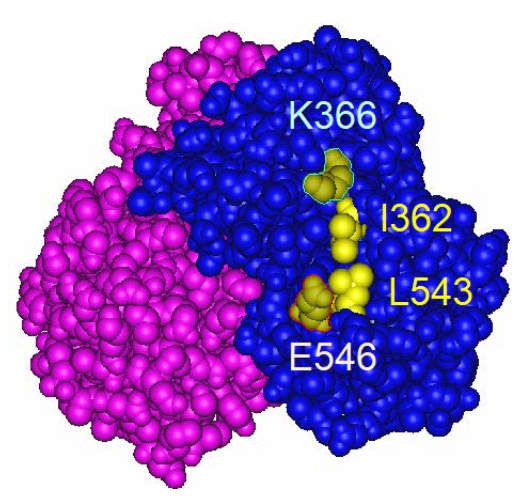

Figure 2. Crystallographic structure of E2-bound LBD dimer of ER $\alpha$. The diagram was generated from the human ER $\alpha$ LBD with 17 $\beta$-E2 (Protein Data Bank ID: 1ERE). The dimer form of pink and blue ER $\alpha$ LBD molecules is shown. The residues suggest the position corresponding to the I362, K366, L543 and E546 of mouse ER $\alpha$. I362 and L543 are hydrophobic amino acids (yellow), K366 is a basic amino acid (blue) E546 is an acidic amino acid (red). 
The agonist activity through $\mathrm{mER} \alpha \mathrm{I} 362 \mathrm{D}$ was not observed as expected. However, it was surprising that the 3x VitERE-mediated transcription of $m E R \alpha$ I362D was activated by a higher concentration (100 nM) of E2 or the synthetic estrogen, diethylstilbestrol (DES), despite no activation of this mutant ER $\alpha$ at lower concentrations (1 and $10 \mathrm{nM})$ of these chemicals [16]. In addition, we observed the reversed antagonist function of SERMs and SERDs through $\mathrm{mER} \alpha$ I362D similar to what was observed with the AF2ER mutant. The agonistic function of the antagonist chemicals, as well as the $100 \mathrm{nM}$ E2 and DES-mediated transcriptional activity was totally eliminated by the truncation of $\mathrm{AB}$-domains of the $\mathrm{mER} \alpha \mathrm{I} 362 \mathrm{D}$ mutant [16]. This result clearly suggested that the ligand-dependent $\mathrm{mER} \alpha$ I362D transactivation function was solely derived from the AF-1 activity.

Experimentally, the activity of ER $\alpha$ AF-1 could be monitored by the LBD truncation from the ER $\alpha$ protein. An LBD truncated mutant, $\mathrm{mER} \alpha 339$ is a ligand independent, constitutively active mutant of $\mathrm{ER} \alpha$, which activity is derived from the AF-1. Interestingly, extending the C-terminus of mER $\alpha 339$ by 45 amino acids (mER $\alpha 384$ ) eliminated the ligand independent transcription activity. The mER $\alpha 384$ mutant contains the LBD region up to helix 3, which includes the I362 residue. Surprisingly, the I362D mutated $\mathrm{mER} \alpha 384(\mathrm{mER} \alpha 384-\mathrm{I362D})$ restored the ligand independent transcription activity [16]. These observations suggest that the region around I362 of helix 3 is involved in blocking of AF-1 activity, which is reduced by the mutation of I362D. The mER $\alpha 384$ that we used in our experiments possesses 14 extra amino acids in the C-terminus which were derived from the expression plasmid. When we added a stop codon at the 385th amino acid position of mouse ER $\alpha$ (mER $\alpha 384$-stop), the activity of mER $\alpha 384$-stop was same as the activity of $\operatorname{mER} \alpha 339$ (unpublished information). The computational prediction of protein secondary structure indicated that the extended 14 amino acids of our mER $\alpha 384$ help to maintain the structure of helix 3 , in contrast with the mER $\alpha 384$-stop, which lost the helix-3 structure (unpublished information). Thus, we believe that the helix 3 of the LBD is involved in the attenuation of AF-1 activity of unliganded ER $\alpha$. Additionally, we found that the transcriptional activity of AF2ER-I362D (triple mutated $\mathrm{mER} \alpha$ ) was more sensitive and potent mutant than the AF2ER mutant. Since, several antagonists that did not activate the AF2ER mutant activated the AF2ER-I362D mutant, and that activity was AF-1-dependent. These results would suggest that the helix-3-mediated AF-1 attenuation activity is disrupted by the I362D mutation. This may be an explanation for the reversed antagonist activity through $\mathrm{mER} \alpha \mathrm{I} 362 \mathrm{D}$ mutant.

There are two possible mechanisms by which the C-terminal LBD can affect the N-terminal AF-1 activity. Specifically, the physical alteration of an ER $\alpha$ protein affects the association between LBD and AF-1 domain or the involvement of cellular factor(s) that may be bridging the LBD and AF-1 domain to control AF-1 activity. To test which mechanism is involved in the connection between LBD and AF-1 domain, we developed a novel method which used the expression plasmids for N-terminal and C-terminal ER $\alpha$ fragments to regulate the reporter gene transcription. The N-terminal ER $\alpha$ expression plasmid contains A through D domains (mER $\alpha \mathrm{ABCD})$. The C-terminal ER $\alpha$ expression plasmid contains E and F domains fused with Gal4 DBD (Gal4DBD-mER $\alpha E F)$. The physically separated ER $\alpha$ expression plasmids were cotransfected with the luciferase reporter plasmid fused with an ERE and a Gal4 responsive element (Gal4RE) combined element (ERE-Gal4RE) (Figure 3). We found that antagonists did not enhance the $\mathrm{N}$-terminal and C-terminal separated AF2ER-I362D-mediated transactivation function differently from the function of the full-length AF2ER-I362D mutant [16]. This result suggested that the physical alteration of an ER $\alpha$ protein is involved in the LBD-mediated AF-1 regulation, instead of the involvement of cellular bridging factors. Additionally, we found that the homo-dimerization activity of AF2ER-I362D-LBD was also induced by antagonists, coinciding with the transcription activity of AF2ER-I362D mutant [16]. It is likely that the prevention of coactivator interaction with the AF-2 allowed the ER $\alpha$ LBD dimerization to occur in a different manner than the dimerization of coactivator interacting ER $\alpha$. This altered dimer structure may be involved in the exposing the N-terminal AF-1 domain for transcriptional activation. 

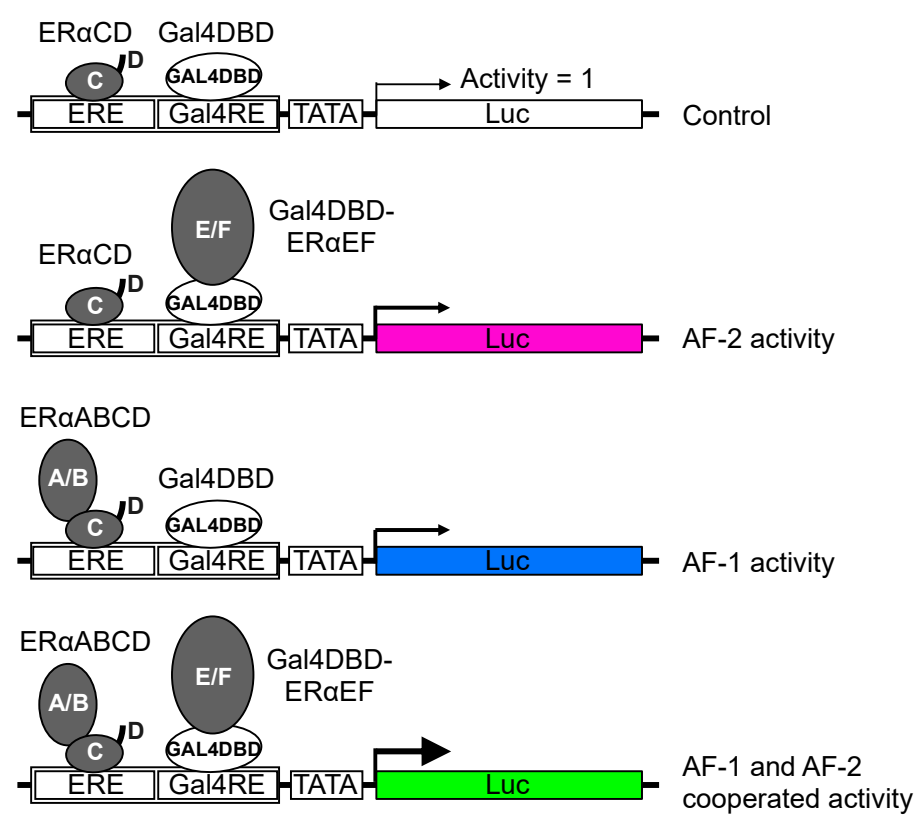

Figure 3. Schematic diagram of a hybrid reporter assay. The activity of reporter gene, which contains a Gal4-binding element (Gal4RE) juxtaposed to an ER binding element (ERE), coexpressed with ER $\alpha$ fragments was analyzed. In experiment, the activities were normalized by the activity of ER $\alpha \mathrm{CD}$ and Gal4DBD expressing cells (Control; white). The cells that were coexpressed with ER $\alpha \mathrm{CD}$ and Gal4DBD-ER $\alpha$ EF demonstrate AF-2 activity (pink). The cells that were coexpressed with ER $\alpha$ ABCD and Gal4DBD demonstrate AF-1 activity (blue). The cells that were coexpressed with ER $\alpha$ ABCD and Gal4DBD-ER $\alpha$ EF demonstrate AF-1 and AF-2 cooperative activity (green).

The physical interaction between the LBD and the N-terminal A-domain of human ER $\alpha$ (1-37 amino acids of $h E R \alpha$ ) had been reported previously [41]. The report of Métvier et al. suggested that the A-domain interacts with the LxxLL motif binding cleft of LBD; the event is associated with the transcriptional inactivation of ligand unbound hER $\alpha$. Our study showed that the LBD possesses an AF-1 inactivation domain and it works through LBD truncated $m E R \alpha$ mutant as well, suggesting that the firm interaction between domains is not necessary for the AF-1 inactivation function. Taken together, these results suggest that the mild interaction of $\mathrm{N}$-terminal structure (i.e., AB-domains) and the LBD may produce transcriptionally quiescent condition of a ligand-unbound $E R \alpha$ molecule. Dissociation of AB-domains from the LBD may be a key step of ligand-dependent ER $\alpha$ activation. The study of Kobayashi et al. suggested that the E2-bound hER $\alpha$ LBD interacts with AB-domains through p300 for transcriptional activation [42]. Recently, the structure of $\mathrm{hER} \alpha$ dimer and coactivators (SRC-3 and p300) complex on the ERE was revealed by using the cryo-EM technique [43]. The structural model suggested that the E2-bound hER $\alpha$ dimer recruits two SRC-3s on the AF-2 domain of each $\mathrm{hER} \alpha$ molecule and one p300 is associated with two SRC-3 molecules. In addition, the report suggested that the AF-1 domain is involved in the SRC-3 recruitment. When the agonists (e.g., E2) bind to the LBD, the cellular factors, such as SRC-3 and p300 may induce the AF- 1 dissociation from the LBD and interact with $\mathrm{AF}-2$, and as a consequence, the factors connect between AF-1 and AF-2 domains. On the other hand, when certain SERMs bind to the LBD, the ligand might induce AF-1 dissociation from the LBD without coactivator recruitment to the AF-2. The formation of LBD dimer with SERMs may be a cause of $\mathrm{AB}$-domains (i.e., $\mathrm{AF}-1$ ) dissociation from the $\mathrm{LBD}$ and the activation of AF-1-dependent transcription.

\section{The F-Domain Functionality for the SERM-Dependent Partial Agonist Activity}

The partial-agonist activity of SERMs and of $4 \mathrm{OHT}$ in particular has been discussed $[44,45]$. The partial-agonist activity of $4 \mathrm{OHT}$ for $\mathrm{ER} \alpha$ is derived from the AF-1-mediated transcription activity [44,46]. However, the molecular mechanism of 4OHT-mediated ER $\alpha$ AF-1 activation is still 
unclear. We found a similarity between the partial-agonist activity of 4OHT for wild-type ER $\alpha$ and the antagonist-mediated AF2ER mutant activation. When we used the wild-type ER $\alpha$-LBD/EF domains for a $\mathrm{M} 2 \mathrm{H}$ assay, we found that $4 \mathrm{OHT}$ is totally unable to activate wild-type $\mathrm{ER} \alpha$-LBD-mediated transcription activity, similar to AF2ER-LBD. As we described above, this allowed us to perform a $\mathrm{M} 2 \mathrm{H}$ assay for examining the 4OHT-dependent homo-dimerization activity of wild-type ER $\alpha$-LBD [47]. The results of the M2H assay clearly suggested that the homo-dimerization of wild-type ER $\alpha$-LBD can be induced by $4 \mathrm{OHT}$. Interestingly, this LBD dimerization activity was strongly attenuated by truncating the F-domain, coinciding with the reduction of the 3x VitERE-mediated transcription activity [35]. These similar characteristics to the AF2ER mutant suggest that the mechanism of 4OHT-mediated activation of wild-type ER $\alpha$ AF-1 may be the same as AF2ER mutant. Principally, 4OHT induces homo-dimerization of ER $\alpha$ providing for enhancement of ERE binding and exposure of AF-1.

Our observations suggested that the F-domain is likely to be involved in the 4OHT-mediated wild-type ER $\alpha$-LBD homo-dimerization. It is known that the ER $\alpha$ LBD structures using X-ray crystallography include only the E-domain but do not include the F-domain [48]. Attempts to resolve the F-domain structure by crystallography using the mouse $\mathrm{ER} \alpha \mathrm{LBD}$ (i.e., $\mathrm{mER} \alpha \mathrm{EF}$ ) have unfortunately been unsuccessful. During these studies of the $\mathrm{mER} \alpha \mathrm{EF}$ protein expression process, we recognized significant proteolysis of the F-domain in the bacterial culture without ligand. Interestingly, this degradation was prevented by the addition to the bacterial culture medium of clomiphene, a SERM like chemical which has similar characteristics as 4OHT [49]. We also applied this procedure for the purification of human $\mathrm{ER} \alpha \mathrm{LBD}$ (i.e., $\mathrm{hER} \alpha \mathrm{EF}$ ), however the F-domain proteolysis of $\mathrm{hER} \alpha \mathrm{EF}$ protein could not be blocked by addition of clomiphene (unpublished observation). The structure of the F-domain and its interactions with other domains of the ER $\alpha$ is still unknown. We presume however that the F-domain is involved and plays a role in the conformational stabilization of $\mathrm{mER} \alpha$ LBD homo-dimer, at least when it binds with $4 \mathrm{OHT}$ or some other SERMs, such as clomiphene.

We noticed that the homology of F-domain between mouse and human ER $\alpha$ proteins is remarkably lower (75.6\% similarity) than the homology to the entire ER $\alpha$ protein $(94.7 \%$ similarity). The differential activities of estrogenic compounds in different species have been considered [50]. Due to the high overall homology of ER $\alpha$ protein among species, it has been thought that the differential metabolisms of chemicals may be the cause of differential estrogenic biological activities rather than species differences of ER $\alpha$ structure. A few studies considered that the structural difference of ER $\alpha$ between animals may contribute to the differential estrogenic activities [51]. Petit et al reported the differential functional amino acids in C-domain using the human-rainbow trout ER $\alpha$ chimera [52]. However, no research has focused on the functionality of the F-domain related to the species difference of ER $\alpha$ action. To assess the functionality of ER $\alpha$ F-domain, we generated chimeric ER $\alpha$ expression constructs having the F-domains of mouse and human receptors exchanged. We analyzed the transcription activity, coactivator interaction activity and LBD homo-dimerization activity of the mouse-human F-domain swapped ER $\alpha$ using cell based in vitro assays [53]. We found that the transcriptional activity of mouse wild-type ER $\alpha$ is more potent than human wild-type $E R \alpha$ under our experimental conditions. 4OHT-mediated differential transcription activities of mouse and human ER $\alpha$ were reversed by F-domain swapping, but not E2-mediated transcription activities. The structure of ER $\alpha$ F-domain is still not known, however, the predicted structures in the F-domain had been reported previously $[54,55]$. Further studies focusing on the predicted $\beta$-strand region in the F-domain revealed that this region is linked with the species difference of 4OHT-mediated ER $\alpha$ transcription activity [53]. Interestingly, there are several species-specific residues in this region (Figure 4). The substitution of three mouse specific residues into the human ER $\alpha$ (hER $\alpha$ TyyiPP) resulted in a similar level of 4OHT-mediated transcription activity as the mouse wild-type ER $\alpha$, but did not alter E2-mediated transcription. Additionally, 4OHT-mediated LBD homo-dimerization activity of hER $\alpha$ TyyiPP-LBD was significantly greater than wild-type $h E R \alpha$-LBD [53]. These results implicate that the F-domain is highly involved in the 4OHT-mediated ER $\alpha$ transcription activity. 


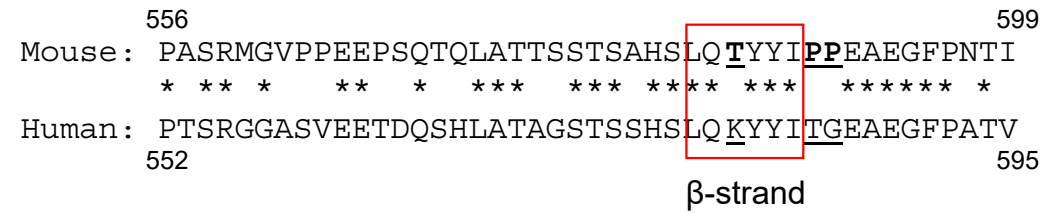

Figure 4. The amino acid sequence of mouse and human ER $\alpha$ F domains. The stars indicate identical amino acids between two species. The region of predicted $\beta$-strand is marked with red square. Mouse specific residues around the predicted $\beta$-strand are denoted as bold letters.

\section{Conclusions}

The transcriptional activity of ER $\alpha$ is regulated by various ligands. Explanation for the differential transcriptional activity of ER $\alpha$ ligands has focused on the activity of ligand-dependent coactivator recruitment to the AF-2. Especially, the importance of ligand-dependent positioning of helix12 for the efficacy of coactivator recruitment has been considered as an explanation for the partial/weak agonist activity of ligands [56,57]. On the contrary, the AF-1-mediated partial agonist activity of SERMs is not explained by the activity of coactivator recruitment to the AF-2. As we described here, the efficacy of SERM-dependent homo-dimer formation is important when considering the AF-1-mediated partial agonist activity of SERMs. This mechanism provides a possible developmental target for the generation of novel SERM chemicals to selectively control ER $\alpha$ AF-1-mediated physiological responses.

\section{Summary}

1. Helix 12 of ER $\alpha$ LBD defines ligands as agonists or antagonists. Antagonists can work as agonists through ER $\alpha$ mutants with a disrupted helix 12 and that transcriptional activity is derived from AF-1.

2. Helix 3 of ER $\alpha$ LBD contributes to the attenuation of AF- 1 activity. Anomalous charge on helix 3 disrupts the LBD functions of AF-1 suppression and AF-2 transactivation.

3. SERMs induce ER $\alpha$ homo-dimerization through the LBD without recruitment of AF-2 coactivators. The AF-1-dependent transcriptional activity of SERMs correlates with the activity of LBD homo-dimerization.

4. The F-domain of ER $\alpha$ contributes to the SERM (4OHT)-dependent LBD homo-dimerization.

Author Contributions: Conceptualization, Y.A.; writing-original draft preparation, Y.A.; writing-review and editing, Y.A. and K.S.K.; supervision, K.S.K.; funding acquisition, K.S.K.

Funding: This study was supported by U.S. National Institutes of Health, National Institute of Environmental Health Sciences (NIEHS) grant 1ZIAES070065 (to KSK) from the Division of Intramural Research of the NIEHS.

Acknowledgments: We thank Sylvia Hewitt and Kathleen Foley for critical reading and editing of the manuscript. We thank Lars Pedersen and the NIEHS X-ray Crystallography Facility for helping with the efforts with the X-ray crystallography analysis.

Conflicts of Interest: The authors declare no conflicts of interest.

\section{Abbreviations}

$\begin{array}{ll}\text { ER } \alpha & \text { Estrogen receptor alpha } \\ \text { SERM } & \text { Selective estrogen receptor modulator } \\ \text { DBD } & \text { DNA binding domain } \\ \text { LBD } & \text { Ligand binding domain } \\ \text { KO } & \text { Knockout } \\ \text { 4OHT } & \text { 4-hydroxytamoxifen } \\ \text { SERD } & \text { Selective estrogen receptor degraders } \\ \text { E2 } & \text { 17ß-estradiol } \\ \text { Vit } & \text { Vitellogenin }\end{array}$




$\begin{array}{ll}\text { M2H } & \text { Mammalian two-hybrid } \\ \text { DES } & \text { Diethylstilbestrol } \\ \text { ERE } & \text { Estrogen responsive element } \\ \text { Gal4RE } & \text { Gal4 responsive element }\end{array}$

\section{References}

1. Greene, G.L.; Gilna, P.; Waterfield, M.; Baker, A.; Hort, Y.; Shine, J. Sequence and expression of human estrogen receptor complementary DNA. Science 1986, 231, 1150-1154. [CrossRef] [PubMed]

2. White, R.; Lees, J.A.; Needham, M.; Ham, J.; Parker, M. Structural Organization and Expression of the Mouse Estrogen Receptor. Mol. Endocrinol. 1987, 1, 735-744. [CrossRef] [PubMed]

3. Koike, S.; Sakai, M.; Muramatsu, M. Molecular cloning and characterization of rat estrogen receptor cDNA. Nucleic Acids Res. 1987, 15, 2499-2513. [CrossRef] [PubMed]

4. Krust, A.; Green, S.; Argos, P.; Kumar, V.; Walter, P.; Bornert, J.M.; Chambon, P. The chicken oestrogen receptor sequence: Homology with v-erbA and the human oestrogen and glucocorticoid receptors. EMBO J. 1986, 5, 891-897. [CrossRef] [PubMed]

5. Huang, P.; Chandra, V.; Rastinejad, F. Structural Overview of the Nuclear Receptor Superfamily: Insights into Physiology and Therapeutics. Annu. Rev. Physiol. 2010, 72, 247-272. [CrossRef] [PubMed]

6. Evans, R.M.; Mangelsdorf, D.J. Nuclear Receptors, RXR, and the Big Bang. Cell 2014, 157, 255-266. [CrossRef] [PubMed]

7. Gronemeyer, H.; Gustafsson, J.-Å.; Laudet, V. Principles for modulation of the nuclear receptor superfamily. Nat. Rev. Drug Discov. 2004, 3, 950-964. [CrossRef]

8. Arao, Y.; Hamilton, K.J.; Ray, M.K.; Scott, G.; Mishina, Y.; Korach, K.S. Estrogen receptor $\alpha$ AF-2 mutation results in antagonist reversal and reveals tissue selective function of estrogen receptor modulators. Proc. Natl. Acad. Sci. USA 2011, 108, 14986-14991. [CrossRef]

9. Arao, Y.; Hamilton, K.J.; Korach, K.S. The Transactivating Function 2 (AF-2) of Estrogen Receptor (ER) $\alpha$ Is Indispensable for ER $\alpha$-Mediated Physiological Responses and AF-1 Activity. OJEMD 2013, 3, 12-19. [CrossRef]

10. Montano, M.M.; Ekena, K.; Krueger, K.D.; Keller, A.L.; Katzenellenbogen, B.S. Human estrogen receptor ligand activity inversion mutants: Receptors that interpret antiestrogens as estrogens and estrogens as antiestrogens and discriminate among different antiestrogens. Mol. Endocrinol. 1996, 10, 230-242.

11. Kato, S.; Endoh, H.; Masuhiro, Y.; Kitamoto, T.; Uchiyama, S.; Sasaki, H.; Masushige, S.; Gotoh, Y.; Nishida, E.; Kawashima, H.; et al. Activation of the estrogen receptor through phosphorylation by mitogen-activated protein kinase. Science 1995, 270, 1491-1494. [CrossRef] [PubMed]

12. Bunone, G.; Briand, P.A.; Miksicek, R.J.; Picard, D. Activation of the unliganded estrogen receptor by EGF involves the MAP kinase pathway and direct phophorylation. EMBO J. 1996, 15, 2174-2183. [CrossRef] [PubMed]

13. Rogatsky, I.; Trowbridge, J.M.; Garabedian, M.J. Potentiation of human estrogen receptor alpha transcriptional activation through phosphorylation of serines 104 and 106 by the cyclin A-CDK2 complex. J. Biol. Chem. 1999, 274, 22296-22302. [CrossRef] [PubMed]

14. Chen, D.; Riedl, T.; Washbrook, E.; Pace, P.E.; Coombes, R.C.; Egly, J.M.; Ali, S. Activation of estrogen receptor alpha by $\mathrm{S} 118$ phosphorylation involves a ligand-dependent interaction with TFIIH and participation of CDK7. Mol. Cell 2000, 6, 127-137. [CrossRef]

15. Curtis, S.W.; Washburn, T.; Sewall, C.; DiAugustine, R.; Lindzey, J.; Couse, J.F.; Korach, K.S. Physiological coupling of growth factor and steroid receptor signaling pathways: Estrogen receptor knockout mice lack estrogen-like response to epidermal growth factor. Proc. Natl. Acad. Sci. USA 1996, 93, 12626-12630. [CrossRef]

16. Arao, Y.; Coons, L.A.; Zuercher, W.J.; Korach, K.S. Transactivation Function-2 of Estrogen Receptor $\alpha$ Contains Transactivation Function-1-regulating Element. J. Biol. Chem. 2015, 290, 17611-17627. [CrossRef] [PubMed]

17. Patel, S.R.; Skafar, D.F. Modulation of nuclear receptor activity by the F domain. Mol. Cell. Endocrinol. 2015, 418, 298-305. [CrossRef] 
18. Kaminetsky, J.; Hemani, M.L. Clomiphene citrate and enclomiphene for the treatment of hypogonadal androgen deficiency. Expert Opin. Investig. Drugs 2009, 18, 1947-1955. [CrossRef]

19. Ahmad, A.; Shahabuddin, S.; Sheikh, S.; Kale, P.; Krishnappa, M.; Rane, R.C.; Ahmad, I. Endoxifen, a New Cornerstone of Breast Cancer Therapy: Demonstration of Safety, Tolerability, and Systemic Bioavailability in Healthy Human Subjects. Clin. Pharmacol. Ther. 2009, 88, 814-817. [CrossRef]

20. Ali, S.; Buluwela, L.; Coombes, R.C. Antiestrogens and Their Therapeutic Applications in Breast Cancer and Other Diseases. Annu. Rev. Med. 2011, 62, 217-232. [CrossRef]

21. Chi, F.; Wu, R.; Zeng, Y.; Xing, R.; Liu, Y.; Xu, Z. Effects of toremifene versus tamoxifen on breast cancer patients: A meta-analysis. Breast Cancer 2012, 20, 111-122. [CrossRef] [PubMed]

22. Pinkerton, J.V.; Pickar, J.H.; Racketa, J.; Mirkin, S. Bazedoxifene/conjugated estrogens for menopausal symptom treatment and osteoporosis prevention. Climacteric 2012, 15, 411-418. [CrossRef] [PubMed]

23. Elkinson, S.; Yang, L.P.H. Ospemifene: First Global Approval. Drugs 2013, 73, 605-612. [CrossRef] [PubMed]

24. D'Amelio, P.; Isaia, G.C. The use of raloxifene in osteoporosis treatment. Expert Opin. Pharmacother. 2013, 14, 949-956. [CrossRef] [PubMed]

25. Vogel, C.L.; Johnston, M.A.; Capers, C.; Braccia, D. Toremifene for Breast Cancer: A Review of 20 Years of Data. Clin. Breast Cancer 2014, 14, 1-9. [CrossRef] [PubMed]

26. Bourguet, W.; Germain, P.; Gronemeyer, H. Nuclear receptor ligand-binding domains: Three-dimensional structures, molecular interactions and pharmacological implications. Trends Pharmacol. Sci. 2000, 21, 381-388. [CrossRef]

27. Mak, H.Y.; Hoare, S.; Henttu, P.M.; Parker, M.G. Molecular determinants of the estrogen receptor-coactivator interface. Mol. Cell. Biol. 1999, 19, 3895-3903. [CrossRef]

28. Brzozowski, A.M.; Pike, A.C.; Dauter, Z.; Hubbard, R.E.; Bonn, T.; Engström, O.; Ohman, L.; Greene, G.L.; Gustafsson, J.A.; Carlquist, M. Molecular basis of agonism and antagonism in the oestrogen receptor. Nature 1997, 389, 753-758. [CrossRef]

29. Shiau, A.K.; Barstad, D.; Loria, P.M.; Cheng, L.; Kushner, P.J.; Agard, D.A.; Greene, G.L. The structural basis of estrogen receptor/coactivator recognition and the antagonism of this interaction by tamoxifen. Cell 1998, 95, 927-937. [CrossRef]

30. Pike, A.C.; Brzozowski, A.M.; Walton, J.; Hubbard, R.E.; Thorsell, A.G.; Li, Y.L.; Gustafsson, J.A.; Carlquist, M. Structural insights into the mode of action of a pure antiestrogen. Structure 2001, 9, 145-153. [CrossRef]

31. Lonard, D.M.; Nawaz, Z.; Smith, C.L.; O'Malley, B.W. The $26 \mathrm{~S}$ proteasome is required for estrogen receptor-alpha and coactivator turnover and for efficient estrogen receptor-alpha transactivation. Mol. Cell 2000, 5, 939-948. [CrossRef]

32. Dauvois, S.; Danielian, P.S.; White, R.; Parker, M.G. Antiestrogen ICI 164,384 reduces cellular estrogen receptor content by increasing its turnover. Proc. Natl. Acad. Sci. USA 1992, 89, 4037-4041. [CrossRef] [PubMed]

33. Arao, Y.; Hamilton, K.J.; Goulding, E.H.; Janardhan, K.S.; Eddy, E.M.; Korach, K.S. Transactivating function (AF) 2-mediated AF-1 activity of estrogen receptor $\alpha$ is crucial to maintain male reproductive tract function. Proc. Natl. Acad. Sci. USA 2012, 109, 21140-21145. [CrossRef] [PubMed]

34. Arao, Y.; Hamilton, K.J.; Lierz, S.L.; Korach, K.S. N-terminal transactivation function, AF-1, of estrogen receptor alpha controls obesity through enhancement of energy expenditure. Mol. Metab. 2018, 18, 68-78. [CrossRef] [PubMed]

35. Arao, Y.; Hamilton, K.J.; Coons, L.A.; Korach, K.S. Estrogen receptor $\alpha$ L543A, L544A mutation changes antagonists to agonists, correlating with the ligand binding domain dimerization associated with DNA binding activity. J. Biol. Chem. 2013, 288, 21105-21116. [CrossRef] [PubMed]

36. Mahfoudi, A.; Roulet, E.; Dauvois, S.; Parker, M.G.; Wahli, W. Specific mutations in the estrogen receptor change the properties of antiestrogens to full agonists. Proc. Natl. Acad. Sci. USA 1995, 92, 4206-4210. [CrossRef] [PubMed]

37. Fawell, S.E.; Lees, J.A.; White, R.; Parker, M.G. Characterization and colocalization of steroid binding and dimerization activities in the mouse estrogen receptor. Cell 1990, 60, 953-962. [CrossRef] 
38. Billon-Galés, A.; Krust, A.; Fontaine, C.; Abot, A.; Flouriot, G.; Toutain, C.; Bergès, H.; Gadeau, A.-P.; Lenfant, F.; Gourdy, P.; et al. Activation function 2 (AF2) of estrogen receptor-alpha is required for the atheroprotective action of estradiol but not to accelerate endothelial healing. Proc. Natl. Acad. Sci. USA 2011, 108, 13311-13316. [CrossRef] [PubMed]

39. Handgraaf, S.; Riant, E.; Fabre, A.; Waget, A.; Burcelin, R.; Lière, P.; Krust, A.; Chambon, P.; Arnal, J.-F.; Gourdy, P. Prevention of obesity and insulin resistance by estrogens requires ER $\alpha$ activation function-2 (ER $\alpha$ AF-2), whereas ER $\alpha$ AF-1 is dispensable. Diabetes 2013, 62, 4098-4108. [CrossRef] [PubMed]

40. Movérare-Skrtic, S.; Börjesson, A.E.; Farman, H.H.; Sjögren, K.; Windahl, S.H.; Lagerquist, M.K.; Andersson, A.; Stubelius, A.; Carlsten, H.; Gustafsson, J.- $\AA$.; et al. The estrogen receptor antagonist ICI 182,780 can act both as an agonist and an inverse agonist when estrogen receptor $\alpha$ AF- 2 is modified. Proc. Natl. Acad. Sci. USA 2014, 111, 1180-1185. [CrossRef] [PubMed]

41. Métivier, R.; Stark, A.; Flouriot, G.; Hübner, M.R.; Brand, H.; Penot, G.; Manu, D.; Denger, S.; Reid, G.; Kos, M.; et al. A dynamic structural model for estrogen receptor-alpha activation by ligands, emphasizing the role of interactions between distant A and E domains. Mol. Cell 2002, 10, 1019-1032. [CrossRef]

42. Kobayashi, Y.; Kitamoto, T.; Masuhiro, Y.; Watanabe, M.; Kase, T.; Metzger, D.; Yanagisawa, J.; Kato, S. p300 mediates functional synergism between AF-1 and AF-2 of estrogen receptor alpha and beta by interacting directly with the N-terminal A/B domains. J. Biol. Chem. 2000, 275, 15645-15651. [CrossRef] [PubMed]

43. Yi, P.; Wang, Z.; Feng, Q.; Pintilie, G.D.; Foulds, C.E.; Lanz, R.B.; Ludtke, S.J.; Schmid, M.F.; Chiu, W.; O'Malley, B.W. Structure of a biologically active estrogen receptor-coactivator complex on DNA. Mol. Cell 2015, 57, 1047-1058. [CrossRef] [PubMed]

44. Berry, M.; Metzger, D.; Chambon, P. Role of the two activating domains of the oestrogen receptor in the cell-type and promoter-context dependent agonistic activity of the anti-oestrogen 4-hydroxytamoxifen. EMBO J. 1990, 9, 2811-2818. [CrossRef] [PubMed]

45. McDonnell, D. The Molecular Pharmacology of SERMs. Trends Endocrinol. Metab. 1999, 10, $301-311$. [CrossRef]

46. Fontaine, C.; Abot, A.; Billon-Galés, A.; Flouriot, G.; Bergès, H.; Grunenwald, E.; Vinel, A.; Valera, M.-C.; Gourdy, P.; Arnal, J.-F. Tamoxifen Elicits Atheroprotection through Estrogen Receptor alpha AF-1 But Does Not Accelerate Reendothelialization. Am. J. Pathol. 2013, 183, 304-312. [CrossRef] [PubMed]

47. Arao, Y.; Korach, K.S. Detecting the Ligand-binding Domain Dimerization Activity of Estrogen Receptor Alpha Using the Mammalian Two-Hybrid Assay. J. Vis. Exp. 2018, e58758. [CrossRef] [PubMed]

48. Eiler, S.; Gangloff, M.; Duclaud, S.; Moras, D.; Ruff, M. Overexpression, purification, and crystal structure of native ER alpha LBD. Protein Expr. Purif. 2001, 22, 165-173. [CrossRef] [PubMed]

49. Clark, J.H.; Markaverich, B.M. The agonistic-antagonistic properties of clomiphene: A review. Pharmacol. Ther. 1981, 15, 467-519. [CrossRef]

50. Hart, J.E. Endocrine Pathology of Estrogens: Species Differnces. Pharmacol. Ther. 1990, 47, 203-218. [CrossRef]

51. Sumida, K.; Ooe, N.; Saito, K.; Kaneko, H. Limited species differences in estrogen receptor alpha-medicated reporter gene transactivation by xenoestrogens. J. Steroid Biochem. Mol. Biol. 2003, 84, 33-40. [CrossRef]

52. Petit, F.G.; Valotaire, Y.; Pakdel, F. The analysis of chimeric human/rainbow trout estrogen receptors reveals amino acid residues outside of $\mathrm{P}$ - and D-boxes important for the transactivation function. Nucleic Acids Res. 2000, 28, 2634-2642. [CrossRef] [PubMed]

53. Arao, Y.; Korach, K.S. The F domain of estrogen receptor $\alpha$ is involved in species-specific, tamoxifen-mediated transactivation. J. Biol. Chem. 2018, 293, 8495-8507. [CrossRef] [PubMed]

54. Schwartz, J.A.; Zhong, L.; Deighton-Collins, S.; Zhao, C.; Skafar, D.F. Mutations targeted to a predicted helix in the extreme carboxyl-terminal region of the human estrogen receptor-alpha alter its response to estradiol and 4-hydroxytamoxifen. J. Biol. Chem. 2002, 277, 13202-13209. [CrossRef] [PubMed]

55. De Vries-van Leeuwen, I.J.; da Costa Pereira, D.; Flach, K.D.; Piersma, S.R.; Haase, C.; Bier, D.; Yalcin, Z.; Michalides, R.; Feenstra, K.A.; Jiménez, C.R.; et al. Interaction of 14-3-3 proteins with the estrogen receptor alpha F domain provides a drug target interface. Proc. Natl. Acad. Sci. USA 2013, 110, 8894-8899. [CrossRef] [PubMed] 
56. Gangloff, M.; Ruff, M.; Eiler, S.; Duclaud, S.; Wurtz, J.M.; Moras, D. Crystal structure of a mutant hERalpha ligand-binding domain reveals key structural features for the mechanism of partial agonism. J. Biol. Chem. 2001, 276, 15059-15065. [CrossRef] [PubMed]

57. Wu, Y.-L.; Yang, X.; Ren, Z.; McDonnell, D.P.; Norris, J.D.; Willson, T.M.; Greene, G.L. Structural basis for an unexpected mode of SERM-mediated ER antagonism. Mol. Cell 2005, 18, 413-424. [CrossRef]

(C) 2019 by the authors. Licensee MDPI, Basel, Switzerland. This article is an open access article distributed under the terms and conditions of the Creative Commons Attribution (CC BY) license (http://creativecommons.org/licenses/by/4.0/). 